\title{
Forbidden Love of Shakespeare's Romeo and Juliet and Fuzûlî’s Layla and Majnun
}

\author{
Nilay Avci \\ Department of English Language Teaching, Faculty of Arts and Science, Çağ University, Mersin, Turkey
}

Email address:

nilayavci@cag.edu.tr

To cite this article:

Nilay Avci. Forbidden Love of Shakespeare's Romeo and Juliet and Fuzûlî’s Layla and Majnun. International Journal of Literature and Arts. Special Issue: World Literature, Comparative Literature and (Comparative) Cultural Studies. Vol. 4, No. 1-1, 2016, pp. 1-4. doi: 10.11648/j.ijla.s.2016040101.11

\begin{abstract}
The aim of this comparative literature study is to discuss two major examples of stories based on the theme of forbidden love. The focus of this study is the love stories of Romeo and Juliet, and Layla and Majnun. While Romeo and Juliet is one of the greatest examples of this theme in Western Literature, the story of Layla and Majnun is one of the most significant expressions of this theme in Old Turkish Literature. Despite the fact that these literary works were created at different times and different places, they both address the same themes that we see throughout the literary traditions of world cultures. This study attempts to explore the reason for these similarities and to locate the origin of these ideas at the essence of human nature and culture. The archetypal essence of the forbidden love theme suggests that it is an ongoing aspect of human consciousness on which many writers have drawn throughout the ages. The role of the writer is to bring these ideas to the awareness of the reader to teach a moral lesson and to elevate the reader through the connection with universal ideas which define the nature of human experience and which are, the archetypes of the collective unconscious.
\end{abstract}

Keywords: Comparative Literature, Forbidden Love, Romeo and Juliet, Layla and Majnun, Shakespeare, Fuzûlî, Collective Unconscious, Archetypes

\section{Introduction}

Throughout history, love has existed in various forms in various works. Love... Isn't it love that makes us to hold on to life when we feel desperate or makes us desperate when everything is well? Yes. This simple four-lettered word stands in opposition to the conflicts in life. It is the better of the two choices. There is no need to use any other words to define love as it has its own nature. You are either in the middle of love or aching for it. As Ovid says, "Love cannot be cured by herbs."

Impossible love is a more attractive and powerful choice of a theme. The immortality of this theme proves its popularity. The deprivation of love in the hope of fulfillment enlarges the attention of the reader. If their love had not been forbidden, most probably this works would not have been as appreciated over the centuries. Maybe this is because every human being hides sad stories deep in their hearts and empathizes with their situations. "This is a love story that is staggering to everybody in the whole world" (Penn, 2007).

Tragic love stories are evidently going to be a source of inspiration for men of letters as long as the world values literary tradition. No matter where the works are written or told, it is inevitable to find many similarities. Romeo and Juliet, the Arthurian romance of Lancelot and Guinevere; Ovid's Pyramus and Thisbe; the Celtic legend of Tristan and Isolde; the Arabian love story of Layla and Majnun; the Kurdish love classic Mem and Zin; Bronte's characters of Wuthering Heights, Catherine and Heathcliff; all share elements of tragic love.

In this study, two major examples of undying love stories, Romeo and Juliet and Layla and Majnun are analyzed and evaluated from a perspective of comparative literature in terms of the theme of forbidden love. The study also attempts to find reasons behind the evolution of these archetypal themes like tragic love; effects of cultural or psychological myths; universal unconscious; and the role of writers' subconscious on the creation of similar works from different times and places.

Romeo and Juliet by William Shakespeare, the greatest writer in English literature, and Layla and Majnun by Fuzûlî, a poet of love, are just two of the most beautiful examples of tragic love stories. Though Romeo and Juliet is an example 
of English Literature and Layla and Majnun is a love story in Old Turkish Literature base on the theme forbidden love, the lovers are under the influence of their families and the moral values.

\section{In Love, Everything is Forbidden: Romeo and Juliet - Layla and Majnun}

Romeo and Juliet is a tragedy of two families, the Montagues and Capulets, who are against the marriage of the two lovers. Romeo has killed a relative of Juliet against his own will and has been banished while Juliet is buried alive as a trick. Thinking that Juliet is really dead, Romeo kills himself.

In Romeo and Juliet, the elements of tragedy originate from external forces, not from the qualities of the characters themselves. There is really no contradiction within Romeo and Juliet's psychologies nor are they in conflict with each other. The situation that drags them into death springs not from their personalities, but from deep enmity between their parents. If the sworn enemies, the Montagues and Capulets get on well with each other, there would be no tragedy. They have no deficiencies which lead them into mischance, no matter what happens (Urgan, 2004, p. 246-47).

It is clearly stated in the play that, even the stars are working against their relationship. According to some beliefs, there is a relation between stars and the fate of human beings. The stars show the fate of the people who control them. Their fate is ruled by the positions of the stars. Every human has a star at birth. If one's star falls from the sky, this person dies or whose star is shining, this person rises (Eyuboğlu, 1987, p. 92).

Related to this belief, as emphasized in the prologue of the tragedy, "the stars" are against this couple:

From forth the fatal loins of these two foes

A pair of star-cross'd lovers take their life;

Whose misadventured piteous overthrows

Do with their death bury their parents' strife.

(Shakespeare, prologue)

When Juliet falls in love with Romeo who is a member of the enemy family, she goes out to her balcony to tell the stars about her strong, but unfortunately forbidden love.

As if things were not bad enough because of sworn enmity between the families, coincidences also cost the young lovers further misfortune. Romeo never meant to kill one of the relatives of Juliet, but unfortunately he did. He was exiled and could not receive the message of Juliet's "death." The messenger could not give the message to Romeo due to a plague. Juliet who was supposedly dead and put into her grave, woke up just one minute after Romeo killed himself... Along with these bad coincidences, the young lovers are sentenced to death because of their environment that does not believe in love by denying it (Urgan, 2004, p. 247).

Lord Capulet, does not know about his daughter's secret marriage to Romeo. He wants his daughter to marry another man. However, she would prefer to be dead instead of living without Romeo or being forced to marry another young man named Paris. In fact, they fall in love and marry each other in secret. They preserve their deep and endless feelings for each other only through death.

On the other hand, Layla and Majnun is too one of the greatest tragic love stories from a different cultural tradition. This immortal story is not so much different than Romeo and Juliet. Similar to Romeo and Juliet's prologue, the destiny of the unfortunate lovers is apparent right from the beginning. Qays is born on the same night Layla is born and no one knows this. Qays cries and cries. As a newborn baby, it is quite natural. However, his reason of crying is mentioned as if he understands what kind of place the world is. Qays is aware that he is born for loving and suffering. He cries for his other half, Layla. That is the reason for his crying.

Layla, who is from a rich tribe in Arabia, and Qays, who is the son of another rich tribe in Arabia, fall in love with each other when they meet in a school called a madrasa. Layla's family hears about it as everyone is talking about their relationship. They stop Layla from going to school, thinking that Layla's attitude towards Qays is a shame for the family. Though Layla denies the rumors, it is too late for her. The young lovers are forbidden to see each other. Years pass by. People start to call Qays "Majnun", meaning madman, driven mad by Layla or possessed by demons or jinn. When Qays' father talks to Layla's family about their marriage, her father says; "I have heard of your fame and it would be an honor to be a relative of yours, but everybody says your son is the one they are calling "Majnun." My daughter does not deserve to marry a madman" (Pala, 2008, p. 30).

Layla's father promises to give his beloved daughter to Qays only if he finds a cure for his son. As a result, the agony of this separation causes Qays to live in the desert with animals, leaving everyone behind. Everyone advises him not to give up. He deserves better, but he cannot forget Layla because his world consists only of her. Layla, who is engaged to a rich man, shares the same agony with Qays because she still loves him. One day, Qays' arm suddenly begins to bleed. His father is anxious and it does not make any sense to him, but Qays explains. A surgeon drew blood from Layla and the effects appear on his arm. Layla is Qays, Qays is Layla, as if they are two persons living in one body. Their love is so powerful that, when she is happy, he becomes happy. If he is sad, she becomes sad.

His father takes Qays to a sacred temple in Mecca with the hope of relieving his pain and giving up his love. However, Qays asks God to make his love even stronger. "Dear God, for Your own sake and for the sake of love, let my love grow stronger with each passing hour. Love is all I have, all I am, and all I ever want to be!” (Pala, 2008, p. 31).

Both Layla and Qays become more miserable day by day. Qays loses all his relations with the world. He lives only with his spirit between death and madness. One day Layla finds him on the desert, but he does not recognize Layla. He is in another dimension and Layla understands the situation that he is in. He reaches a level of spirituality that destroys his mentality. Eventually, his physical love turns into a divine 
love. He thinks that his pain is the essence of real love and he does not want to be released from this agony. "Oh, God," he prays, "Let me know the pain of love. Do not, for even a moment, separate me from it" (Pala, 2008, p. 31). In this work, the dominant theme is the more you suffer from love, the more it helps you to become closer to the real one, God.

Fuzûlî's notion of love, however, has more in common with the Sufi idea of love as a projection of the essence of God than it does with the Western idea of romantic love (wikipedia.org).

They both die in the end, the same as Romeo and Juliet. The lover and the loved becomes one. They are no longer two separate persons. The conclusion clearly elaborates the death of the lovers, but not the death of love (Guinhutt, 1998).

Instead of struggling to gain his love, Majnun turns Layla into a perfectly divine being in his head. He chooses his crying and poetry as salvation and release from his abandonment. He is mentally alienated. Layla is too perfect to be human. Love, longing and desperation for the opposite sex in Layla and Majnun exceed human limits. Nevertheless, every being is a part of God. For this reason, Majnun is longing to reach God, the source of everything. Layla becomes only a way to God for Majnun. He turned her into an instrument of God. In the end, there remains no resemblance between the real Layla and the Layla he created in his mind. Then he dies out of his love madness. At this point, his love for Layla should be questioned. Does he really deserve her love when we consider the fact that nothing is gained without struggling?

We should also question Romeo's love for Juliet because, before seeing her, he was mourning for the love of Rosaline. He claimed that no one could be as perfect as she. His friend Benvolio advises him to forget her and find another one :

Tut man, one fire burns out another's burning;

One pain is lessened by another's anguish.

Turn giddy, and be helped by backward turning.

One desperate grief cures with another's languish.

Take thou some new infection to thy eye,

And the rank poison of the old will die.

(Shakespeare, II. ii)

He takes the advice and never speaks a word about Rosaline again because once he sees Juliet, his unrequited love for Rosaline seems irrelevant to him. He speaks to Juliet as if it was somebody else feeling sad about Rosaline. He speaks as though he has known Juliet for a long time:

With love's light wings did I o'er-perch these walls;

For stony limits cannot hold love out,

And what love can do that dares love attempt;

Therefore thy kinsmen are no let to me.

(Shakespeare, II. ii)

After Rosaline refused to marry him, his sadness leads him to doubt the reality of the world and especially of love. "Love is a smoke made with the fume of sighs" (I. i) Love is nothing but "a madness most discreet" (I. i.) until Romeo sees Juliet. He easily forgets Rosaline when he falls in love with Juliet. If he was really in love with Rosaline, he would not go out to look for another woman. So, if he meets another woman, Juliet would be the same position with Rosaline. Maybe, he is not really in love with Juliet, but he is just charmed by her beauty. This situation proves that in both of the stories, a woman's love seems more real because women, naturally, are associated with deep emotions like love, more so than men. Juliet and Layla may be more capable of having deeper emotions than Romeo and Majnun.

\section{A Journey through the Writers' and the Readers' Mind}

When we look over Shakespeare and Fuzûlî's life, it will not come as a surprise for anyone to learn that both the writers have suffered a lot in their lives. Fuzûlî's life brings him misfortune, destitution and disappointment. His condition affects him deeply and this feeling of loneliness becomes an inspiration for his art. His suffering is justified by the notion that love is directly related to God. Different from Western sense of romantic love, Fuzûlî thinks every beautiful thing is an instrument to reach God. Shakespeare's life is also full of misfortune. He marries Anne Hathaway, an older woman whom he does not love. Because of her pregnancy, her family forces him to marry their daughter. The family dies out without having direct descendants of Shakespeare. His sexuality is another subject to be questioned. There are some hints about his sexual preferences in some of his works. Whether it is a love for a human being or divine love, the two authors' characters reflect the experience of their own lives.

No matter how hard the writer tries, he inevitably reveals himself by mentioning some parts of his own life. In fact, everything they create is a reflection of their lives. The connection between reader and writer occurs when the reader links to the emotional experience of writer through the characters the writer creates. On the other hand, as human beings, we all create an ideal man, woman or relationship in our minds. When our dreams do not meet the reality, it leads to heartbreak and disappointment. These similarities between the diverse contributions to world literature are the products of Carl Gustav Jung's archetypes and collective unconscious. Jung (1981) states that archetypes are complexes of experience that come upon us like fate, and their effects are felt in our most personal life (p. 30) and there are as many archetypes as there are typical situations in life (p. 48). He defines archetypes as timeless forms that find psychic expressions in images. He sees them as giving substance to the collective unconscious, an inherited psychic structure present in all human beings. The archetypes in the collective unconscious surface in the conscious level of the mind and shape its content. As a result, various myths and rituals derive from those archetypes in various cultures across time (Lawson, 2008, p. 8). As human beings, our collective unconscious is somehow connected to each other from birth. Each individual builds his own experience of life, shaped by cultural content, characteristics and perspective. 
The archetypes, along with our personal memories and experiences common to all humanity, become a part of universal unconscious. To Jung, these archetypes are shared by all the people from various cultures, independent of time and place (stenudd.com). The archetypes first lie at the root of the instincts. But beyond that, they have come, in human form at least, to serve to temper or counterbalance the instincts. The archetypes give form to the instincts and to the collective unconscious, of which the instincts are a subset (Güzeldere, 1995, p. 112-113).

\section{Conclusion}

In spite of the cultural differences, both of the works are based on archetypal themes. The only difference is, in Romeo and Juliet, there is hate and violence in addition to love and passion. In Layla and Majnun, when love becomes truly impossible, Majnun's love exceeds the limit of human love, turning into divine love.

Within the framework of Jung's perceptions, the reason for creating the tragic characters of Romeo and Juliet, Layla and Majnun, or choosing the theme of forbidden love as the subject for an article, is that the literary expression of these themes is rooted in the archetypes of the collective unconscious. Ponte and Schäfer (2013) summarize the view by saying that "the universe itself is consciousness and that our own consciousness is connected with the cosmic consciousness."

To conclude, these two works are timeless classics which still affect readers and the forbidden love theme is one of the most favorite and preferred subjects of poetry, books and movies. Both Romeo and Juliet and Layla and Majnun stories are the proof that in love, everything is forbidden. Regarding this fact, most people admire the strength of their love because to be loved and love like them is the realization of an archetypal essence which informs humanity and creates unity among the literary traditions of world cultures from the ancient world to the present.

\section{References}

[1] Eyuboğlu, İ. Z. (1987). Anadolu İnançları Anadolu Mitolojisi İnanç - Söylence Bağlantısı, İstanbul: Geçit Kitabevi

[2] Fuzûlî. Retrived June 15, 2015 from Wikipedia: http://en.wikipedia.org/wiki/Fuzûlî

[3] Guinhut, J. P. , (1998) The Man Who Loved Too Much: The Legend of Leyli and Majnun. Azerbaijan International 6.3, 33-38. Retrived January 16, 2012 from http://azer.com/aiweb/categories/magazine/63_folder/63_artic les/63_legendleyli.html

[4] Jung, C.G. (1981). The Archetypes and the Collective Unconscious. Bollington Series, Princeton University Press.

[5] Jung's Collective Unconscious. Retrived June 16, 2015 from: http://www.stenudd.com/myth/freudjung/jungcollectiveunconscious.htm

[6] Lawson, T.T. (2008). Carl Jung, Darwin of the Mind. London: Karnac

[7] Lawson, T.T. (2008). Darwin of the Mind: 36. In Güven Güzeldere (1995): Problems of consciousness: a perspective on contemporary issues, current debates. Journal of consciousness studies, 2 (2): 112-43

[8] Pala, İ. (2008). Leylâ ile Mecnun. İstanbul: Kap1 Yayınları

[9] Penn, S. (Director). (2007). Into the Wild [biographical drama film]. United States

[10] Ponte, D.V. \& Schäfer, L. (2013). Carl Gustav Jung, Quantum Physics and the Spiritual Mind: A Mystical Vision of the Twenty-First Century. Behavioral sciences, 3: 601-618

[11] Shakespeare, W. (2006). Romeo and Juliet. İstanbul: Akyüz Yayınları

[12] Shakespeare, W. (2008). Romeo ve Juliet. İstanbul: Remzi Kitabevi

[13] Shakespeare's Life. Retrived June 15, 2015 from http://www.folger.edu/shakespeares-life

[14] Urgan, M. (2004). İngiliz Edebiyatı Tarihi. İstanbul: YKY 